\title{
Pengaruh Karakteristik Perusahaan pada Pengungkapan Tanggung Jawab Sosial Perusahaan
}

\author{
Herkulanus Bambang Suprasto ${ }^{1}$ \\ Angelia Putri Surya Haryanti ${ }^{2}$ \\ 1,2 Fakultas Ekonomi dan Bisnis Universitas Udayana, Indonesia \\ email: bambangsuprasto@yahoo.com
}

DOI: https://doi.org/10.24843/JIAB.2019.v14.i02.p07

\section{Jurnal Ilmiah Akuntansi dan Bisnis (JIAB)}

https://ojs.unud.ac.id/index.php/jiab/ user/profile

Volume 14

Nomor 2

Juli 2019

Halaman 219-229

p-ISSN $\underline{2302-514 X}$

e-ISSN $\underline{2303-1018}$

\section{INFORMASI ARTIKEL}

Tanggal masuk:

20 Januari 2019

Tanggal revisi:

25 Juni 2019

Tanggal terima:

01 Juli 2019

\begin{abstract}
ABSTRAK
Tujuan penelitian ini memberi bukti empiris pengaruh karakteristik perusahaan yang meliputi umur perusahaan, ukuran perusahaan, profitabilitas, dan ukuran dewan komisaris pada corporate social responsibility disclosure. Penelitian ini dilakukan pada perusahaan yang terdaftar di Bursa Efek Indonesia dengan periode pengamatan selama 3 tahun yaitu dari tahun 2015-2017. Sampel penelitian ini berjumlah 52 perusahaan dengan jumlah pengamatan sebanyak 110 amatan. Metode penentuan sampel menggunakan teknik purposive sampling. Hasil penelitian menunjukkan umur perusahaan dan ukuran perusahaan berpengaruh positif pada corporate social responsibility disclosure, sedangkan profitabilitas dan ukuran dewan komisaris tidak dapat dibuktikan berpengaruh pada corporate social responsibility disclosure. Hasil penelitian ini juga memberi bukti konkrit penerapan dan penjelasan mekanisme bekerjanya stakeholder theory sebagai Teori dasar penelitian.
\end{abstract}

Kata kunci : Karakteristik perusahaan, corporate social responsibility disclosure

\section{The Influence of Firm's Characteristics on Corporate Social Responsibility Disclosure}

\begin{abstract}
This study aimed to provide empirical evidence on the effect of firm characteristics which include firm age, firm size, profitability, and board of commissioner size, on corporate social responsibility disclosure for firms listed on the Indonesia Stock Exchange. This research was conducted on firms listed on the Indonesia Stock Exchange with an observation period of 3 years, from 2015 to 2017. The sample of this study amounted to 52 firms with a total of 110 observations. A purposive sampling approach was used as the method of determining the sample used. The results showed that firm age and firm size had a positive effect on corporate social responsibility disclosure, while profitability and board of commissioner size cannot be proven to have no effect on corporate social responsibility disclosure. The results of this research also provide concrete evidence of the application and explanation of the mechanism of stakeholder theory as a grand theory of this study.

Keywords : Company characteristics, corporate social responsibility disclosure
\end{abstract}

\section{PENDAHULUAN}

Perusahaan didirikan bukan hanya untuk jangka waktu yang singkat, namun untuk jangka waktu yang lama. Hal ini mengindikasikan semakin lama perusahaan berdiri maka semakin besar dampak yang akan ditimbulkan bagi lingkungan sekitar. Rengganis \& Putri (2018) menyatakan perusahaan dalam upaya mempertahankan kelangsungan hidupnya selain untuk memperoleh laba juga memiliki tanggungjawab sosial. 
Bowen (2014) mengungkapkan tingkat kesuksesan perusahaan dalam menjalankan bisnis bergantung dari kontribusi yang dilakukan terhadap kesejahteraan masyarakat. Hubungan antara perusahaan dan stakeholder ini dijelaskan dengan konsep Corporate Social Responsibility (CSR). Konsep CSR adalah sekumpulan aturan maupun praktek mengenai hubungan antara pemangku kepentingan, pengaplikasian aturan hukum, image di masyarakat maupun lingkungan, begitu pula komitmen perusahaan untuk ikut serta dalam pembangunan berkelanjutan (Subiantoro \& Mildawati, 2015).

Oktariani \& Mimba (2014) mengungkapkan CSR adalah sebuah konsep yang menjelaskan tentang tanggung jawab perusahaan kepada pemangku kepentingan (stakeholder) maupun pihak lain yang terkena dampak dari kegiatan operasional perusahaan. Wulandari \& Suprasto (2015) juga menyatakan CSR merupakan salah satu faktor yang memiliki pengaruh terhadap respon investor dalam pengambilan keputusannya terkait penanaman modal di perusahaan. Implementasi CSR di Indonesia sudah mulai diterapkan sejak ditetapkan Undang-Undang (UU) No. 40 Tahun 2007 sesuai Pasal 74 ayat (1) serta diperkuat dengan diterbitkannya Peraturan Pemerintah (PP) No. 47 Tahun 2012.

Upaya mendorong implementasi CSR telah dilakukan oleh IAI terkait transparansi serta akuntabilitas yakni dengan penyelenggaraan ajang penghargaan yang dikenal dengan Indonesia Sustainability Reporting Awards (ISRA) di tahun 2005. ISRA itu sendiri ditujukan bagi perusahaanperusahaan yang sudah melakukan CSR guna pemeliharaan pembangunan keberlanjutan (sustainability) perusahaan, dimana laporan ini dapat diterbitkan tersendiri ataupun terintegrasi dalam laporan tahunan (annual report) (Kurnianingsih, 2013).

\section{Tabel 1. Jumlah Perusahaan di BEI dan Jumlah Perusahaan yang Mengikuti} Indonesia Sustainability Reporting Awards (ISRA)

\begin{tabular}{|c|c|c|c|c|}
\hline \multirow[t]{2}{*}{ Sektor perusahaan } & \multirow[t]{2}{*}{$\begin{array}{c}\text { Jumlah perusahaan } \\
\text { di BEI (per } 31 \\
\text { Desember 2017) }\end{array}$} & \multicolumn{3}{|c|}{$\begin{array}{l}\text { Jumlah perusahaan yang } \\
\text { mengikuti Indonesia } \\
\text { Sustainability Reporting } \\
\text { Awards (ISRA) }\end{array}$} \\
\hline & & 2015 & 2016 & 2017 \\
\hline Pertanian & 19 & 0 & 1 & 0 \\
\hline Pertambangan & 45 & 6 & 4 & 3 \\
\hline Industri Dasar dan Kimia & 68 & 2 & 1 & 1 \\
\hline Aneka Industri & 44 & 0 & 0 & 0 \\
\hline Indsutri Barang Konsumsi & 46 & 1 & 0 & 0 \\
\hline Properti dan Real Estate & 64 & 1 & 1 & 1 \\
\hline $\begin{array}{l}\text { Infrastruktur, Utilitas dan } \\
\text { Transportasi }\end{array}$ & 61 & 2 & 2 & 2 \\
\hline Keuangan & 89 & 5 & 4 & 4 \\
\hline Perdagangan, Jasa dan Investasi & 131 & 1 & 1 & 2 \\
\hline TOTAL & 567 & 18 & 14 & 13 \\
\hline
\end{tabular}

Sumber: NCSR (2012)

Tabel 1 menunjukkan dari 567 perusahaan yang terdaftar di Bursa Efek Indonesia selama periode 2015-2017 hanya sekitar 3,2 persen perusahaan yang mengikuti ISRA di tahun 2015, 2,5 persen di tahun 2016 dan 2,3 persen di tahun 2017. Penghargaan ISRA yang dikeluarkan oleh National Center for Sustainability Reporting (NCSR) ini merupakan penghargaan atas kelengkapan informasi lingkungan dan sosial yang disajikan dalam website dalam mempromosikan pembangunan berkelanjutan (sustainable development). Laporan Keberlanjutan atau juga sering dikenal dengan "Laporan CSR" adalah laporan yang memuat kinerja perusahaan dalam tiga aspek yaitu Ekonomi, Lingkungan dan Sosial. "Laporan ini menjadi sarana bagi para pemangku kepentingan (stakeholder) untuk menilai sejauh mana perusahaan mengatasi isu keberlanjutan seperti penghematan dan konservasi energi, pengelolan air, pengelolaan limbah, mengatasi pencemaran udara serta isu sosial seperti partisipasi perusahaan dalam meningkatkan kualitas hidup masyarakat setempat" (NCSR, 2012). Berdasarkan 
data yang ditunjukkan Tabel 1 menunjukkan masih banyak perusahaan di Indonesia yang belum melaksanakan kewajiban CSR.

Riset-riset terdahulu menunjukkan penerapan CSR dipengaruhi beberapa faktor diantaranya umur perusahaan, ukuran perusahaan, profitabilitas, leverage, likuiditas, solvabilitas, kepemilikan manajerial, dan ukuran dewan komisaris. Faktorfaktor tersebut merupakan parameter dari karakteristik perusahaan. Manurung \& Muid (2015) menunjukkan ukuran dewan komisaris dan kepemilikan asing berpengaruh positif terhadap pengungkapan tanggung jawab sosial perusahaan. Sedangkan ukuran perusahaan, profitabilitas dan leverage tidak menunjukkan pengaruh terhadap pengungkapan tannggung jawab sosial perusahaan.

Hasil penelitian Kamil \& Herusetya (2012) menunjukkan profitabilitas, likuiditas dan solvabilitas tidak berpengaruh terhadap luas pengungkapan kegiatan corporate social responsibility, sedangkan ukuran perusahaan berpengaruh positif terhadap luas pengungkapan kegiatan corporate social responsibility.

Sementara, Manurung \& Muid (2015) menunjukkan size dari dewan komisaris serta kepemilikan asing memiliki pengaruh yang positif pada pengungkapan CSR perusahaan. Sedangkan size perusahaan, rasio profitabilitas maupun leverage tidak menunjukkan pengaruh pada pengungkapan tannggung jawab sosial perusahaan.

Sunaryo (2013) meneliti perusahaan properti dan real estate yang terdaftar di BEI, menunjukkan company size dan profitability memiliki pengaruh yang positif terhadap variabel corporate social responsibility disclosures, sementara company ages maupun leverage tidak menunjukkan pengaruh terhadap variabel pengungkapan tannggung jawab sosial perusaahaan.

Dewi \& Priyadi (2013) yang meneliti perusahaan manufaktur yang terdaftar di BEI, menunjukkan ukuran perusahaan, kepemilikan manajerial, serta ukuran dewan komisaris memiliki pengaruh positif pada corporate social responsibility disclosure (CSRD), sedangkan profitabilitas maupun leverage tidak memiliki pengaruh pada corporate social responsibility disclosure (CSRD). Sementara Penelitian lain oleh Bowman \& Haire (1975) menunjukkan rata-rata return on equity (ROE) berpengaruh secara signifikan terhadap corporate social responsibility.

Perusahaan dalam menjalankan operasionalnya tentunya akan berinteraksi dengan banyak pihak, seperti pemangku kepentingan. Pemangku kepentingan mencakup orang per seorangan maupun kelompok yang saling memengaruhi sebagai akibat akan aktivitas yang dilakukan (Freeman, 1999). Teori pemangku kepentingan menjelaskan bahwa perusahaan tidak hanya beroperasi untuk kepentingan internal saja, melainkan harus memberikan timbal balik positif bagi pemangku kepentingan (Manurung $\&$ Muid, 2015).

Stakeholder merupakan individu atau kelompok yang saling memengaruhi satu sama lain sebagai dampak dari aktivitas-aktivitasnya (Freeman, 1999). Teori pemangku kepentingan (stakeholder theory) menyatakan perusahaan bukanlah entitas yang hanya beroperasi untuk kepentingannya sendiri, namun harus memberikan manfaat bagi stakeholder (pemegang saham, kreditur, konsumen, supplier, pemerintah, masyarakat, analisis dan pihak lain) (Manurung \& Muid, 2015). Sejalan dengan hal tersebut Dkhili \& Ansi (2014) menjelaskan stakeholder theory merupakan tindakan perusahaan untuk membangun kepercayaan antara perusahaan dengan stakeholder. Penjelasan tersebut menunjukkan bahwa keberadaan suatu perusahaan sangat dipengaruhi oleh dukungan yang diberikan oleh stakeholder.

Teori stakeholder juga menyatakan kelangsungan hidup dan keberhasilan perusahaan bergantung pada pemenuhan kebutuhan ekonomi dan nonekonomi dengan cara menyeimbangkan kepentingan stakeholder perusahaan (Pirsch \& Grau, 2007). Beberapa alasan yang mendorong perusahaan perlu memperhatikan kepentingan stakeholder, yaitu: 1) Isu lingkungan melibatkan kepentingan berbagai kelompok dalam masyarakat yang dapat mengganggu kualitas hidup mereka. 2) Dalam era globalisasi telah mendorong produkproduk yang diperdagangkan harus bersahabat dengan lingkungan. 3) Investor dalam menanamkan modalnya cenderung untuk memilih perusahaan yang memiliki dan mengembangkan kebijakan dan program lingkungan. 4) LSM dan pencinta lingkungan makin vokal dalam mengkritik perusahaan perusahaan yang kurang peduli terhadap lingkungan (Sunaryo, 2013).

Corporate social responsibility disclosure atau pengungkapan tannggung jawab sosial mulai berkembang seiring dengan konsep CSR yang disampaikan World Business Council for Sustainable Development (WBSD) tahun 1995. Corporate social responsibility disclosure adalah sebuah konsep yang membicarakan tentang dampak sosial dan lingkungan dari kegiatan perusahaan untuk para pemangku kepentingan (Hastuti, 2014). 
Corporate social responsibility disclosure ini dituangkan melalui laporan keberlanjutan perusahaan dalam konteks pembangunan berkelanjutan (sustainable development) yang isinya terkait dengan keadaan ekonomi, lingkungan sosial, kinerja perusahaan. Pengungkapan tanggung jawab sosial perusahaan dilaksanakan secara sukarela (voluntary disclosure) karena tidak tergolong bagian dari laporan keuangan (pengungkapan minimum) yang disyaratkan oleh standar akuntansi yang berlaku. Penjelasan tersebut menunjukkan bahwa pengungkapan tanggung jawab sosial masih belum memiliki standar yang baku sehingga prosedur dan item pengungkapan bergantung kepada kebijakan dari perusahaan.

Karakteristik perusahaan menggambarkan sifat khusus yang ada di perusahaan dan terlihat dari beberapa aspek seperti bidang usaha, komposisi kepemilikan, rasio likuiditas, rasio profitabilitas, ukuran perusahaan. Umur perusahaan mencirikan kemampuan perusahaan di dalam menjaga eksistensinya atau bertahan. Umur perusahaan diperkirakan mempunyai arah yang positif dengan kualitas pengungkapan sukarela (Nugroho, 2012). Penjelasan tersebut menunjukkan semakin lama perusahaan dapat bertahan maka semakin besar kemungkinan perusahaan mengungkapkan informasi sosialnya sebagai bentuk tanggung jawabnya agar tetap diterima di masyarakat (Oktariani \& Mimba, 2014).

Size adalah salah satu variabel yang dipergunakan terkait penjelasan untuk pengungkapan di laporan keuangan perusahaan tahunan (Sunaryo, 2013). Undang-Undang (UU) No. 20 Tahun 2008 menjelaskan ukuran perusahaan dapat dikategorikan menjadi empat, dilihat dari jumlah penjualan dan aset yang dimiliki perusahaan yakni perusahaan mikro, perusahaan kecil, perusahaan menengah, dan perusahaan besar.

Fahrizqi (2010) dalam Manurung \& Muid (2015) menyatakan rasio profitabilitas merupakan faktor penentu terkait kinerja oleh perusahaan dalam mendapatkan laba menggunakan sumber yang dimilikinya. Profitabilitas menempati posisi penting dalam suatu perusahaan dan juga bagi stakeholder karena dengan profitabilitas yang tinggi maka kesejahteraan stakeholder akan terjamin dan kebutuhan-kebutuhan mereka akan terpenuhi (Goal, 2010 dalam Rosiana et al., 2013).

Dewan komisaris merupakan salah satu bagian dari shareholder untuk perusahaan yang berjenis perseroan terbatas. Dewan komisaris berwenang sebagai pengendalian internal terkait pengelolaan perusahaan oleh manajerial, serta dapat berwenang untuk menentukan bagaimana pihak manajemerial memenuhi tugasnya dalam pengembangan dan pelaksanaan internal control perusahaan (Subiantoro \& Mildawati, 2015).

Karakteristik perusahaan yang dimaksud mencakup umur perusahaan, ukuran perusahaan, profitabilitas, dan ukuran dewan komisaris. Umur perusahaan menggambarkan kemampuan perusahaan untuk tetap bertahan dalam dunia bisnis. Penjelasan tersebut mengindikasikan umur perusahaan pastinya memiliki kaitan secara positif dengan kualitas pengungkapan CSR (Utami \& Prastiti, 2016). Umur perusahaan berpengaruh positif terhadap pengungkapan tanggung jawab sosial perusahaan (Putri, 2013). Konsisten dengan penelitian Putri, penelitian (Untari, 2010) menyatakan umur perusahaan secara parsial berpengaruh terhadap pengungkapan tanggung jawab sosial perusahaan barang konsumsi.

Penjabaran tersebut konsisten dengan konsep dasar Teori Konsep dasar teori stakeholder. Konsep dasar teori stakeholder adalah bahwa semakin kuat hubungan korporasi, maka akan semakin baik bisnis korporasi. Sebaliknya, semakin buruk hubungan korporasi maka akan semakin sulit. Hubungan yang kuat dengan para pemangku kepentingan adalah berdasarkan kepercayaan, rasa hormat, dan kerjasama. Teori stakeholder adalah sebuah konsep manajemen strategis, tujuannya adalah untuk membantu korporasi memperkuat hubungan dengan kelompok-kelompok eksternal dan mengembangkan keunggulan kompetitif (Totok, 2014).

Perusahaan yang telah lama beroperasi tentunya mempunyai hubungan baik dengan pemangku kepentingan sehingga tidak menutup kemungkinan terciptanya ikatan emosional antara perusahaan dengan stakeholder. Upaya menjaga ikatan emosional ini akan mendorong terbentuknya rasa tanggung jawab dari perusahaan untuk melaksanakan kegiatan dan pengungkapan CSR guna menjaga hubungan baik dengan stakeholder terebut.

Perusahaan yang sudah lama menjalin hubungan dengan stakeholder tentu mengetahui informasi yang dibutuhkan stakeholder untuk menjaga ikatan antara perusahaan dengan stakeholder. Kondisi ini yang menyebabkan perusahaan yang sudah lama berdiri akan dapat memberikan banyak informasi tentang tanggung jawab social perusahaan yang dibutuhkan stakeholder. Berdasarkan uraian tersebut dirumuskan hipotesis berikut: 
$\mathrm{H}_{1}$ : Umur perusahaan berpengaruh positif pada corporate social responsibility disclosure.

Ukuran Perusahaan (Size) digambarkan dengan jumlah assets perusahaan yang besar dan secara tidak langsung menunjukkan banyak dan luasnya aktivitas perusahaan serta memiliki akibat yang lebih tinggi pada lingkungannya terutama kepada stakeholder, sehingga pelaporan tanggung jawab sosial sudah menjadi sebuah kewajiban (Cowen \& Carolina, 1987). Penelitian Kamil \& Herusetya (2012) menyatakan ukuran perusahaan berpengaruh secara positif terhadap pengungkapan tanggung jawab sosial perusahaan. Konsisten dengan penelitian Kamil \& Herusetya (2012), Utami \& Prastiti (2013) menyatakan size terbukti berpengaruh positif terhadap social responsibility disclosure.

Perusahaan besar yang lazimnya didukung sumber daya manusia yang berkompeten dan memahami konsep going concern perusahaan serta tanggung jawab sosial perusahaan, sehingga perusahaan akan lebih mampu untuk melaksanakan kegiatan dan pengungkapan CSR. Berdasarkan uraian tersebut dirumuskan hipotesis berikut:

$\mathrm{H}_{2}$ : Ukuran perusahaan berpengaruh positif pada corporate social responsibility disclosure.

Tingkat profitabilitas adalah indikator bagaimana perusahaan dapat menghasilkan laba dengan memanfaatkan sumber-sumber yang dimilikinya seperti aset atau ekuitas (Fahrizqi, 2010 dalam Manurung \& Muid, 2015). Hubungan pengungkapan CSR dan profitabilitas menunjukkan semakin tinggi profitabilitas perusahaan mencerminkan kemampuan perusahaan dalam menghasilkan dana untuk melaksanakan tanggung jawab sosialnya, serta melakukan pengungkapan tanggung jawab sosial dalam laporan tahunan. Profitabilitas dapat menunjukkan bagaimana kebijakan dan keputusan manajemen perusahaan di dalam mengelola dana, baik itu sumber maupun penggunaan dana dalam menjalankan operasional perusahaan. Salah satu sumber dana perusahaan berasal dari pihak stakeholder sehingga pengungkapan profitabilitas kepada stakeholder menjadi hal yang krusial dan penting dilakukan oleh perusahaan.

Penelitian Sunaryo (2013) menyatakan profitabilitas secara signifikan berpengaruh terhadap variabel corporate social responsibility disclosures. Konsisten dengan penelitian Sunaryo (2013), penelitian Utami \& Prastiti (2013) menyatakan net profit margin terbukti berpengaruh secara positif dan signifikan terhadap social disclosure.
Perusahaan dengan tingkat profitabilitas yang tinggi menunjukkan kemampuan perusahaan menghasilkan sumber daya utuk membiayai aktivitasnya. Penjelasan tersebut menunjukkan tingginya laba perusahaan akan mendorong perusahaan dalam melaksanakan kegiatan sosial sehingga memungkinkan perusahaan melakukan pengungkapan informasi sosial juga akan meningkat (Hackston \& Milne, 1996).

$\mathrm{H}_{3}$ : Profitabilitas berpengaruh positif pada corporate social responsibility disclosure.

Dewan komisaris adalah wakil shareholder dalam perusahaan yang diharapkan dapat bersifat adil dan netral. Penelitian Manurung \& Muid (2015) menyatakan ukuran dewan komisaris berpengaruh positif terhadap pengungkapan tanggung jawab sosial perusahaan. Konsisten dengan penelitian Manurung \& Muid (2015), penelitian Amalia (2013) menunjukkan ukuran dewan komisaris memiliki pengaruh pada pengungkapan CSR perusahaan yang terdaftar di Bursa Efek Indonesia. Perusahaan dengan jumlah anggota dewan komsiaris yang banyak cenderung memberikan tekanan atau pengawasan lebih tinggi pada manajemen, yang tentunya akan memaksa perusahaan memberikan informasi secara menyeluruh salah satunya informasi tentang kegiatan CSR (Collier \& Gregory, 1999).

$\mathrm{H}_{4}$ : Ukuran dewan komisaris berpengaruh positif pada corporate social responsibility disclosure.

\section{METODE PENELITIAN}

Penelitian dilakukan pada Bursa Efek Indonesia dengan mengakses laporan tahunan maupun laporan sustainability perusahaan periode 2015-2017. Data-data yang diperlukan tersebut diakses melalui web www.idx.co.id dengan obyek penelitian corporate social responsibility disclosure.

Corporate social responsibility disclosure (CSRD) dalam penelitian diukur dengan menggunakan indeks GRI (Global Reporting Initiative) versi G4 yaitu sebanyak 91 item, dengan mengacu kepada tiga aspek (Pflieger et al., 2005). Standar GRI digunakan berdasarkan pertimbangan Standar GRI mewakili praktik terbaik secara global dalam hal pelaporan dampak ekonomi, lingkungan dan sosial kepada public (https:// www. global reporting.org).

Rumus menghitung indeks kelengkapan pengungkapan adalah sebagai berikut (Aulia \& Syam, 2013): 


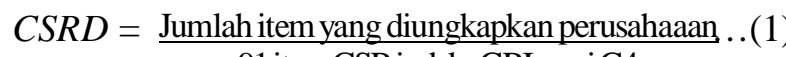
91 item CSR indeks GRI versi G4

Umur perusahaan (UP) menggunakan umur dari tanggal perusahaan listing di Bursa Efek Indonesia (Grougiou, et al., 2015). Rumus umur perusahaan adalah sebagai berikut (Grougiou et al., 2015):

UP = Tahun pengamatan - Tahun listing di BEI.....(2)

Ukuran Perusahaan (Size) diukur menggunakan logaritma natural guna menghindari tingginya nilai yang dihasilkan. Rumus ukuran perusahaan adalah sebagai berikut (Wahyuni et al., 2013):

Size $=\operatorname{Ln}($ total aset $)$

Profitabilitas (Gross profit margin) diukur menggunakan proksi gross profit margin dikarenakan untuk menghindari bias akibat laba bersih perusahaan yang bernilai negatif. Rumus gross profit margin adalah sebagai berikut (www.analisis.co.id):

Gross profit margin $=\frac{\text { Laba Kotor }}{\text { Penjualan }} \times 100 \%$..........

Ukuran Dewan Komisaris (DK) yang diharapkan bersifat adil dan netral biasanya mampu menekan manajemen untuk mengungkapkan informasi yang lebih luas kepada pemangku kepentingan. Variabel ini diukur dengan perhitungan yang diadopsi dari Amalia (2013):

DK $=\underset{\text { Jumlah Dewan Komisaris minimal menurut UC No } 40 \text { Tahun } 2007}{\text { Jumlah Dewan Komisaris diPenushaan }}$

Sampel penelitian mengacu pada perusahaan di Bursa Efek Indonesia periode 2015-2017 yang dihasilkan dari metode purposive sampling dengan kriteria : (1) Perusahaan listing di Bursa Efek Indonesia periode 2015-2017, (2) Perusahaan melaporkan dan mempublish laporan tahunan maupun laporan sustainability di web resmi Bursa Efek Indonesia maupun di web resmi perusahaan periode 2015-2017, dan (3) Perusahaan mengungkapkan program CSR dengan kriteria indeks GRI G4 dalam laporan tahunan maupun laporan sustainability periode 2015-2017.

Data dikumpulkan dengan metode observasi nonpartisipan dan metode dokumentasi dengan jenis data yang dipakai berupa data kualitatif yang dikuantitatifkan dan data kuantitatif dengan sumber data yaitu data sekunder. Mendahului analisis data maka pertama-tama dilakukan uji pelanggaran asumsi klasik guna menghasilkan model penelitian yang bersifat BLUE (best linear unbiased estimator). Setelah dilakukan uji tersebut maka dilakukan analisis data menggunakan regresi linear berganda. Persamaan regresi linear berganda pada penelitian ini adalah sebagai berikut.

$$
\begin{aligned}
& Y=\alpha+\beta_{1} X_{1}+\beta_{2} X_{2}+\beta_{3} X_{3}+\beta_{4} X_{4}+\varepsilon \\
& \text { Keterangan : } \\
& \mathrm{Y}=\text { Corporate Social Responsibility } \\
& \text { Disclosure (CSRD) } \\
& \alpha=\text { Konstanta } \\
& \mathrm{X}_{1} \quad=\text { Umur Perusahaan (UP) } \\
& \mathrm{X}_{2} \quad=\text { Ukuran Perusahaan (Size) } \\
& \mathrm{X}_{3} \quad=\text { Profitabilitas (Gross profit margin) } \\
& \mathrm{X}_{4} \quad=\text { Ukuran Dewan Komisaris (DK) } \\
& \beta_{1}, \beta_{2}, \beta_{3}, \beta_{4}=\text { Koefisien regresi } \\
& \varepsilon=\text { standard error }
\end{aligned}
$$

\begin{tabular}{|c|c|c|}
\hline Keterangan & & Jumlah \\
\hline $\begin{array}{l}\text { Perusahaan yang terdaftar di Bursa Efek Indonesia periode } \\
\text { 2015-2017. } \\
\text { Perusahaan yang tidak mempublikasikan laporan tahunan } \\
\text { maupun laporan sustainability di web resmi Bursa Efek } \\
\text { Indonesia maupun di web resmi perusahaan antara periode } \\
\text { 2015-2017. }\end{array}$ & & $(515)$ \\
\hline \multirow[t]{4}{*}{$\begin{array}{l}\text { Perusahaan mengungkapkan program CSR dengan kriteria } \\
\text { indeks GRI G4 dalam laporan tahunan maupun laporan } \\
\text { sustainability antara periode 2015-2017. }\end{array}$} & & 52 \\
\hline & 2015 & 37 \\
\hline & 2016 & 35 \\
\hline & 2017 & 38 \\
\hline Jumlah P & matan & 110 \\
\hline
\end{tabular}

\section{HASIL DAN PEMBAHASAN}

Pemilihan sampel yang dilakukan dengan pertimbangan-pertimbangan tertentu menghasilkan sebanyak 52 perusahaan sebagai sampel.

\section{Tabel 2. Hasil Penyeleksian Sampel}

Sumber: Data diolah, 2018 
Berdasarkan data yang dikumpulkan dan data yang disajikan dalam Tabel 3. pengelolaan secara statistik diperoleh deskripsi

Tabel 3. Statistik Deskriptif Data

\begin{tabular}{lccccc}
\hline & $\mathrm{N}$ & Minimum & Maximum & Mean & Std. Deviation \\
\hline Umur Perusahaan & 110 & 3,00 & 35,00 & 18,57 & 7,78 \\
Ukuran Perusahaan & 110 & 28,37 & 34,66 & 31,46 & 1,45 \\
Profitabilitas & 110 & 0,01 & 1,00 & 0,40 & 0,28 \\
Ukuran Dewan & 110 & 1,50 & 5,00 & 3,26 & 0,72 \\
Komisaris & 110 & 0,09 & 0,88 & 0,45 & 0,19 \\
CSRD & 110 & & & & \\
Valid N (listwise) & 110
\end{tabular}

Sumber: Data diolah, 2018

Berdasarkan Tabel 3 untuk umur perusahaan mempunyai nilai minimum 3,00 , nilai maksimum 35,00 , nilai rata-rata (mean) 18,57 , dan standar deviasi 7,78. Nilai standar deviasi menunjukkan nilai yang cukup, hal menunjukkan data umur perusahaan memiliki sebaran data yang cukup merata (data penelitian heterogen).

Ukuran perusahaan $\left(\mathrm{X}_{2}\right)$ mempunyai nilai minimum 28,37, nilai maksimum 34,66, nilai rata-rata (mean) 31,46, dan standar deviasi 1,45. Nilai standar deviasi menunjukkan nilai yang kecil, menunjukkan data ukuran perusahaan memiliki sebaran data yang terpusat. Hal ini menunjukkan sampel penelitian cenderung homogen.

Profitabilitas $\left(\mathrm{X}_{3}\right)$ mempunyai nilai minimum 0,01 , nilai maksimum 1,00 , nilai rata-rata (mean) 0,40 , dan standar deviasi 0,28. Nilai standar deviasi menunjukkan nilai yang kecil, menunjukkan data ukuran perusahaan memiliki sebaran data yang terpusat. Hal ini menunjukkan sampel penelitian cenderung homogen.
Ukuran dewan komisaris $\left(\mathrm{X}_{4}\right)$ mempunyai nilai minimum 1,50 , nilai maksimum 5,00, nilai rata-rata (mean) 3,26, dan standar deviasi 0,72. Nilai standar deviasi menunjukkan nilai yang kecil, menunjukkan data ukuran dewan komisaris memiliki sebaran data yang terpusat. Hal ini menunjukkan sampel penelitian cenderung homogen.

Corporate social responsibility disclosure (Y) mempunyai nilai minimum 0,09 dan nilai maksimum 0,88 dengan rata-rata (mean) 0,45 , dan standar deviasi 0,19 . Nilai standar deviasi menunjukkan nilai yang kecil, menunjukkan data Corporate social responsibility disclosure memiliki sebaran data yang terpusat. Hal ini menunjukkan sampel penelitian cenderung homogen.

Sebelum dilakukan uji statistik telah dilakukan uji pelanggaran asumsi klasik atas data yang diperoleh. Hasil pengujian meliputi uji normalitas data, uji multikolinearitas, uji autokorelasi dan uji heteroskedastisitas. Hasil pengujian menunjukkan data penelitian lolos uji pelanggaran asumsi klasik. Hasil uji statistik penelitian disajikan dalam Tabel 4.

Tabel 4. Hasil Uji Statistik

\begin{tabular}{|c|c|c|c|c|c|}
\hline \multirow[t]{2}{*}{ Variabel } & \multicolumn{2}{|c|}{$\begin{array}{c}\text { Unstandardized } \\
\text { Coefficients }\end{array}$} & \multirow{2}{*}{$\begin{array}{c}\text { Standardized } \\
\text { Coefficients } \\
\text { Beta } \\
\end{array}$} & \multirow[t]{2}{*}{$\mathrm{t}$} & \multirow[t]{2}{*}{$\begin{array}{c}P- \\
\text { value }\end{array}$} \\
\hline & $\mathrm{B}$ & Std.Error & & & \\
\hline Constant & $-0,495$ & 0,318 & & $-.1,556$ & 0,123 \\
\hline Umur Perusahaan & 0,019 & 0,002 & 0,743 & 9,986 & 0,000 \\
\hline Ukuran Perusahaan & 0,022 & 0,011 & 0,167 & 2,047 & 0,043 \\
\hline Profitabilitas & $-0,084$ & 0,052 & 0,121 & $-1,617$ & 0,109 \\
\hline Ukuran Dewan Komisaris & $-0,023$ & 0,022 & $-0,086$ & $-1,060$ & 0,292 \\
\hline$R$ Square & & & & & 0,523 \\
\hline Adjusted R Square & & & & & 0,505 \\
\hline $\mathrm{F}$ & & & & & 28,818 \\
\hline$P$-value $\mathrm{F}$ & & & & & 0,000 \\
\hline
\end{tabular}

Sumber: Data diolah, 2018 
Berdasarkan Tabel 4 maka persamaan regresi linear berganda yang dipergunakan dalam penelitian ini dirumuskan sebagai berikut.

$\mathrm{Y}=-0,495+0,019 \mathrm{X}_{1}+0,022 \mathrm{X}_{2}-0,084 \mathrm{X}_{3}-$

$0,023 \mathrm{X}_{4}$

Konstanta persamaan regresi tersebut sebesar -0,495 dan hasil $P$-value sebesar 0,123 menunjukkan bahwa konstanta dalam penelitian ini tidak memiliki makna. Koefisien regresi $\mathrm{X}_{1}$ sebesar 0,019 dengan hasil $P$-value sebesar 0,000 yang mengindikasikan jika umur perusahaan $\left(\mathrm{X}_{1}\right)$ bertambah 1 satuan mengakibatkan CSRD (Y) akan naik 0,019.

Koefisien regresi $\mathrm{X}_{2}$ menunjukkan hasil 0,022 dan $P$-value sebesar 0,043 yang mengindikasikan bahwa jika ukuran perusahaan $\left(\mathrm{X}_{2}\right)$ bertambah 1 satuan mengakibatkan $C S R D(\mathrm{Y})$ akan naik 0,022 satuan. Koefisien regresi $\mathrm{X}_{3}$ menunjukkan hasil sebesar -0,084 dengan $P$-value sebesar 0,109 yang menunjukkan jika profitabilitas $\left(\mathrm{X}_{3}\right)$ bertambah 1 satuan akan mengakibatkan CSRD (Y) turun 0,084 satuan. Koefisien regresi $\mathrm{X}_{4}$ menunjukkan hasil sebesar -0.023 dengan $P$-value sebesar 0,292 yang berarti jika ukuran dewan komisaris $\left(\mathrm{X}_{4}\right)$ bertambah 1 akan mengakibatkan $C S R D(\mathrm{Y})$ mengalami penurunan sebesar 0.023 satuan.

Nilai uji F hitung sebesar 28,818 dengan $P$-value sebesar 0,000, hasil uji $\mathrm{F}$ tersebut menunjukkan model penelitian ini layak. Hasil uji F ini menjelaskan bahwa variabel umur perusahaan, ukuran perusahaan, profitabilitas dan ukuran dewan komisaris yang digunakan dalam penelitian ini mampu menjelaskan variable Corporate social responsibility disclosure.

Nilai uji determinan (Adjusted $R$ Square) sebesar 0,505 menunjukkan corporate social responsibility disclosure sebesar 50,50 persen dapat dijelaskan oleh umur perusahaan, ukuran perusahaan, profitabilitas, dan ukuran dewan komisaris. Semetara 49,50 persen dijelaskan oleh variabel lainnya yang tidak digunakan dalam penelitian.

Berdasarkan Tabel 4. hasil uji statistik menunjukkan variabel umur perusahaan memiliki nilai koefisien regresi sebesar 0,019 dengan $P$-value sebesar $0,000<0,05$. Berdasarkan hasil uji statistik tersebut hipotesis 1 terbukti. Hasil uji statistik tersebut menunjukkan bahwa umur perusahaan berpengaruh positif pada corporate social responsibility disclosure. Hal ini menunjukkan semakin lama berdiri perusahaan semakin memahami perkembangan kebutuhan informasi tanggungjawab sosial yang dibutuhkan stakeholder. Hasil pengujian ini konsisten dengan konsep CSR yang menyatakan bahwa perusahaan akan melakukan kegiatan dan pengungkapan CSR guna menjaga hubungan baik dengan pihak stakeholder dengan kata lain umur perusahaan memiliki hubungan positif dengan kualitas pengungkapan CSR (Utami \& Prastiti, 2016). Ikatan emosional ini akan mendorong terbentuknya rasa tanggung jawab dari perusahaan untuk melaksanakan kegiatan dan pengungkapan CSR. Hasil penelitian ini sejalan dengan penelitian Putri (2013) dan Untari (2010) yang menyatakan bahwa umur perusahaan berpengaruh positif pada corporate social responsibility disclosure.

Berdasarkan Tabel 4 pengujian kedua menunjukkan ukuran perusahaan mempunyai koefisien regresi 0,022 dengan $P$-value sebesar 0,043 . Hasil uji menunjukkan ukuran perusahaan berpengaruh positif pada corporate social responsibility disclosure, dengan demikian hipotesis 2 terbukti. Ukuran perusahaan berkaitan dengan aspek manajemen perusahaan yang ditunjukkan dengan kualitas dari sumber daya manusia yang dimiliki oleh perusahaan. Semakin besar perusahaan maka semakin memadai sumber daya yang dimiliki.

Ukuran perusahaan menggambarkan kemampuan suber daya manusia yang dimiliki sehingga perusahaan besar memiliki kemampuan yang memadai dalam pengungkapan informasi tanggungjawab sosial perusahaan dalam laporan tahunan perusahaan. Perusahaan besar biasanya memiliki aktivitas yang lebih kompleks dan mempunyai dampak yang lebih besar terhadap lingkungannya terutama kepada stakeholder, sehingga pelaporan tanggung jawab sosial sudah menjadi sebuah kewajiban (Cowen \& Carolina, 1987).

Perusahaan besar didukung oleh sumber daya manusia yang memadai yang memahami konsep keberlangsungan hidup perusahaan (sustainable) serta tanggung jawab sosial perusahaan, dengan demikian perusahaan mampu untuk melaksanakan kegiatan dan pengungkapan CSR. Hasil penelitian ini sejalan dengan penelitian Kamil \& Herusetya (2012), Utami \& Prastiti (2013), Hastuti (2014), dan Dewi \& Priyadi (2013) yang menyatakan ukuran perusahaan berpengaruh positif pada corporate social responsibility disclosure.

Hasil pengujian ketiga menunjukkan profitabilitas mempunyai koefisien regresi sebesar - 0,084 dengan $P$-value sebesar 0,109 , hasil pengujian ini menunjukkan hasil uji statistik tidak dapat membuktikan hipotesis ketiga. Profitabilitas yang dengan menggunakan rasio laba bruto tidak menjamin besarnya kemauan perusahaan untuk melakukan pengungkapan CSR. Penjelasan tersebut menunjukkan bahwa perusahaan yang melakukan CSR (pengungkapan atas kegiatan CSR) hanya 
didasarkan pemenuhan ketentuan Undang-Undang, sehingga pelaksanaannya tidak tergantung dari tingkat profitabilitas perusahaan. Hasil penelitian ini konsisten dengan penelitian Kamil \& Herusetya (2012), Dewi \& Priyadi (2013), Manurung \& Muid (2015), dan Kurnianingsih (2013) yang menyatakan profitabilitas tidak berpengaruh pada corporate social responsibility disclosure.

Hasil pengujian ke empat menunjukkan ukuran dewan komisaris mempunyai koefisien regresi sebesar -0,023 dengan $P$-value sebesar 0,292, hasil uji ini menunjukkan penelitian ini tidak dapat membuktikan hipotesis keempat. Undang-Undang No. 40 Tahun 2007 menyatakan bahwa syarat minimal anggota dewan komisaris yang dimiliki oleh perusahaan adalah 2 orang. Pengujian yang dilakukan tidak dapat membuktikan adanya pengaruh jumlah anggota dewan komisaris dengan corporate social responsibility disclosure. Penjelasan tersebut menunjukkan bahwa kegagalan ini mungkin karena perekrutan dewan komisaris untuk kebutuhan perusahaan hanya didasarkan ketentuan yang ada bukan karena kebutuhan perusahaan. Hal itu dibuktikan data ukuran dewan komisaris memiliki sebaran data yang terpusat yang menunjukkan sampel penelitian cenderung homogen. Dalam hal ini perusahaan menentukan jumlah anggota dewan komisaris hanya untuk memenuhi persyaratan yang ada di dalam ketentuan Undang-Undang. Hasil penelitian ini konsisten dengan penelitian Oktariani \& Mimba (2014) dan Trisnawati (2014) yang menyatakan ukuran dewan komisaris tidak berpengaruh pada corporate social responsibility disclosure.

Hasil penelitian ini berimplikasi pada kebijakkan perusahaan karena dalam menjalankan operasionalnya tidak hanya dihadapkan pada aktivitas untuk mengejar laba (profit) melainkan juga harus memperhatikan dan terlibat pada pemenuhan kesejahteraan masyarakat (people), serta turut berkontribusi aktif dalam menjaga pelestarian lingkungan (planet).

Ukuran perusahaan juga dapat menggambarkan aspek manajemen yang dimiliki oleh perusahaan. Aspek manajemen ini ditunjukkan dengan kualitas dari sumber daya manusia yang dimiliki oleh perusahaan. Perusahaan besar didukung oleh sumber daya manusia yang memadai dan yang memahami konsep keberlangsungan hidup perusahaan (going concern) serta tanggung jawab sosial perusahaan, sehingga perusahaan akan lebih mampu untuk melaksanakan kegiatan dan pengungkapan CSR. Secara keseluruhan hasil penelitian berimplikasi pada proses penetapan tujuan organisasi dan pengembangan kebijakan serta perencanaan untuk membantu perusahaan dalam menguatkan hubungan dengan kelompok-kelompok eksternal dan mengembangkan keunggulan kompetitif.

\section{SIMPULAN}

Berdasarkan hasil empat pengujian yang telah dilakukan, dua pengujian mendukung hipotesis yakni: (1) Umur perusahaan berpengaruh positif pada corporate social responsibility disclosure, dan (2) Ukuran perusahaan berpengaruh positif pada corporate social responsibility disclosure. Sementara dua pengujian lain tidak dapat membuktikan hipotesis yang telah dirumuskan yakni variabel profitabilitas dan ukuran dewan komisaris tidak terbukti berpengaruh pada corporate social responsibility disclosure.

Berdasarkan hasil pengujian tersebut dapat disimpulkan Umur perusahaan berpengaruh positif pada corporate social responsibility disclosure dan ukuran perusahaan berpengaruh positif pada corporate social responsibility disclosure. Sementara Profitabilitas dan ukuran dewan komisaris tidak terbukti berpengaruh positif pada corporate social responsibility disclosure.

Berdasarkan hasil pengujian menunjukkan umur perusahaan yang menggambarkan lama berdirinya perusahaan tentunya juga menggambarkan pengalaman perusahaan dalam memahami dan memenuhi kebutuhan stakeholder. Lama berdirinya perusahaan juga menunjukkan kemampuan perusahaan dalam melihat perkembangan kebutuhan mayasarakat akan informasi, sehingga semakin lama umur perusahaan akan semakin informasi tanggungjawab social yang diungkap.

Ukuran perusahaan yang ditunjukkan dengan total asset yang yang dimiliki menggambarkan besar perusahaan dan luas usaha. Besar dan luas usaha menggambarkan jumlah dan kapasitas sumber daya manusia yang dimiliki, sehingga semakin besar perusahaan akan memiliki kemampuan mengungkap informasi tanggungjawab social yang dibutuhkan masyarakat.

Rekomendasi yang dapat diberikan berdasarkan hasil penelitian ini adalah bagi perusahaan penyusunan laporan berkelanjutan (sustainability report) dalam upaya pengungkapkan tanggung jawab sosial yang telah dilakukan untuk memenuhi kewajiban sesuai regulasi yang ada tetapi merupakan bagian dari startegi perusahaan. Perusahaan dapat menggunakan pengungkapan tanggungjawab sosial 
dalam laporan berkelanjutan sebagai media implementasi rencana strategis perusahaan.

\section{REFERENSI}

Amalia, D. (2013). Pengaruh Karakteristik Perusahaan Terhadap Corporate Social Responsibility Disclosure Di Bursa Efek Indonesia. Media Riset Akuntansi, 3(1), 3447.

Analis.co.id. Analisis rasio gross profit margin \& rumus dan contoh soal margin laba kotor. 11 agustus 2018. (https://analis.co.id/grossprofit-margin.html). Diakses 01 September 2018

Aulia, A., \& Syam, D. (2013). Pengaruh Karakteristik Perusahaan terhadap Praktek Pengungkapan Sustainability Reporting Dalam Laporan Tahunan Perusahaan Publik di Indonesia Adistira Sri Aulia. Jurnal Reviu Akuntansi Dan Keuangan, 3(1), 403-414.

Bowen, H. R. (2014). The Interpretation of Voting in the Allocation of Economic Resources. Oxford Journals, 58(1), 27-48.

Bowman, E. H., \& Haire, M. (1975). A Strategic Posture Toward Corporate Social Responsibility. WINTER International Journal, XVIII(2), 4958.

Collier, P., \& Gregory, A. (1999). Audit committee activity and agency costs. Journal of Accounting and Public Policy, 18, 311-332.

Cowen, S. S., \& Carolina, N. (1987). The Impact Of Corporate Characteristics On Social Responsibility Disclosure/ : A Typology And Frequency-Based Analysis. Journal of Accounting Organizations and Society, 12(2), 111-122.

Dewi, S., \& Priyadi, M. (2013). Pengaruh Karakteristik Perusahaan Terhadap Corporate Social Responsibilitydisclosure Pada Perusahaan Manufaktur. Jurnal Ilmu \& Riset Akuntansi, 2(3), 1-20.

Dkhili, H., \& Ansi, H. (2014). responsabilitè sociètale et performance financière dans les entreprises tunisiennes. Journal of La Revue Des Science de Gestion, 3, 43-50. https://doi.org/10.3917/ rsg.267.0043

Freeman, R. E. (1999). Divergent Stakeholder Theory. Academy Of Management Review, 24(2), 233-237.

Grougiou, V., Leventis, S., Dedoulis, E., \& Owusuansah, S. (2015). Corporate Social Responsibility and Earnings Management in $U$. S .
International Hellenic University Journal, 233(0), 1-48.

Hackston, D., \& Milne, M. J. (1996). Some determinants of social and environmental disclosures in New Zealand companies. Accounting, Auditing \& Accountability Journal, 9(1), 77-108.

Hastuti, W. (2014). Pengaruh Ukuran Perusahaan, Pertumbuhan Perusahaan, dan Tipe Industri Terhadap Pengungkapan Tanggung Jawab Sosial Perusahaan Dalam Laporan Tahunan (Studi Empiris pada perusahaan Manufaktur yang listing di BEI). E-Journal Universitas Negeri Padang, 1-18.

Kamil, A., \& Herusetya, A. (2012). Pengaruh Karakteristik Perusahaan Terhadap Luas Pengungkapan Kegiatan Corporate Social Responsibility. Media Riset Akuntansi, 2(1), 1-17.

Kurnianingsih, H. (2013). Pengaruh profitabilitas dan size perusahaan terhadap corporate social responsibility. Jurnal Riset Akuntansi Dan Bisnis, 13(1), 93-111.

Manurung, E., \& Muid, D. (2015). Pengaruh Karakteristik Perusahaan Terhadap Pengungkapan Tanggung Jawab Sosial. Diponegoro Journal Of Accounting, 4(2), 1-9.

Nugroho, A. S. (2012). Pengaruh Karakteristik Perusahaan Terhadap Tingkat Keluasan Pengungkapan Laporan Keuangan Pada Sektor Industri Makanan Dan Minuman Yang Terdaftar Di Bursa Efek Indonesia. Jurnal Ilmu \& Riset Akuntansi, 1(12), 1-27.

Oktariani, N. W., \& Mimba, N. P. S. H. (2014). Pengaruh karakteristik perusahaan dan tanggung jawab lingkungan pada pengungkapan tanggung jawab sosial perusahaan. E-Jurnal Akuntansi Universitas Udayana, 3(6), 402-418.

Pflieger, J., Fischer, M., Kupfer, T., \& Eyerer, P. (2005). The contribution of life cycle assessment to global sustainability reporting of organizations. Management of Enviromental Quality: An International Journal, 16(2), 167-179. https:/ /doi.org/10.1108/14777830510583182

Pirsch, J., \& Grau, S. L. (2007). A Framework for Understanding Corporate Social Responsibility Programs as a Continuum/ : An Exploratory Study. Journal of Business Ethics, 70, 125126. https://doi.org/10.1007/s10551-006-9100-y Putri, C. D. (2013). Pengaruh Corporate Governance Dan Karakteristik Perusahaan Terhadap Pengungkapan Tanggung Jawab Sosial Perusahaan Di Dalam Sustainability Report 
(Studi Empiris Perusahaan Yang Terdaftar Di BEI). E-Journal Universitas Negeri Padang, (September), 1-27.

Rengganis, R. M. Y. D., \& Putri, I. G. A. M. A. D. (2018). Pengaruh Corporate Governance dan Pengungkapan Corporate Social Responsibility Terhadap Agresivitas Pajak. E-Jurnal Akuntansi Universitas Udayana, 24(2), 871-898.

Rosiana, G. A. M. E., Juliarsa, G., \& Sari, M. M. R. (2013). Pengaruh pengungkapan csr terhadap nilai perusahaan dengan profitabilitas sebagai variabel pemoderasi. E-Jurnal Akuntansi Universitas Udayana, 3(5), 723-738.

Subiantoro, O. H., \& Mildawati, T. (2015). Pengaruh Karakteristik Perusahaan Terhadap Pengungkapan CSR. Jurnal Ilmu \& Riset Akuntansi, 4(7), 1-11.

Sunaryo. (2013). Pengaruh Company Size , Company Ages, Profitability, Dan Leverage Terhadap Csr Disclosures Pada Kelompok Perusahaan Properti Dan Real Estate. Journal The WINNERS, 14(1), 61-69.

Totok, Mardikanto. (2014). CSR (Corporate Social Responsibility) (Tanggung Jawab Sosial Perusahaan). Alfabeta, Bandung, hlm. 68.

Trisnawati, R. (2014). Pengaruh Ukuran Perusahaan, Profitabilitas, Leverage, Ukuran Dewan Komisaris dan Kepemilikan Manajerial Terhadap Pengungkapan Corporate Social
Responsibility (CSR) Industri Perbankan di Indonesia. Seminar Nasional Dan Call For Paper, (October), 27-32.

Untari, L. (2010). Effect On Company Characteristic Corporate Social Responsibility Disclosure in Corporate Annual Report of Consumption Listed in Indonesia Stock Exchange. E-Journal Universitas Gunadarma, 1-17.

Utami, S., \& Prastiti, S. D. (2016). Pengaruh Karakteristik Perusahaan Terhadap Social Disclosure. Jurnal Ekonomi Bisnis, 1, 63-69.

Wahyuni, T., Ernawati, E., \& Marhudi, W. R. (2013). Faktor-faktor yang mempengaruhi nilai perusahaan di sektor. Jurnal Ilmiah Mahasiswa Universitas Surabaya, 2(1), 1-18.

Wulandari, I. A. T., \& Suprasto, H. B. (2015). Konservatisme Akuntansi, Good Corporate Governance Dan Pengungkapan Corporate Social Responsibility Pada Earnings Response Coefficient. E-Jurnal Akuntansi Universitas Udayana, 1(13), 173-190.

www.ncsr-id.org. ISRA2012 - Sewindu Penghargaan "Sustainability Reporting" (Laporan Keberlanjutan) di Indonesia dan Kini Merambah ke Asia Tenggara. 23 Desember 2012. (https:// www.ncsr-id.org/2012/12/23/isra-2012-sewindupenghargaan-sustainability-reporting-laporankeberlanjutan-di-indonesia-dan-kini-merambahke-asia-tenggara/). diakses tanggal 24 Juni 2019. 